\title{
Disarmament, Demobilisation and Reintegration of Armed Groups in Post-war Sri Lanka: A Study based on Koralaipattu South Divisional Secretariat Division in Eastern Sri Lanka
}

\author{
V. Kamalasiri ${ }^{1}$, M. A. M. Fowsar ${ }^{1} \&$ M. M. Fazil ${ }^{1}$ \\ ${ }^{1}$ Department of Political Science, South Eastern University of Sri Lanka, Sri Lanka \\ Correspondence: V. Kamalasiri, Department of Political Science, South Eastern University of Sri Lanka, Sri \\ Lanka.E-mail: kamalsv08@seu.ac.lk
}

Received: July 18, 2020

doi:10.5539/jpl.v13n3p236
Accepted: August 29, $2020 \quad$ Online Published: August 30, 2020

URL: https://doi.org/10.5539/jpl.v13n3p236

\begin{abstract}
This article generally focuses on the process of Disarmament, Demobilization and Reintegration (DDR) which are essential to restore sustainable peace in the post-war scenario. The DDR is one of the significant aspects of the process of post-war peacebuilding. In most of the cases, this process has implemented with the assistance of foreign governments and international or regional institutions. However, the circumstances under which the Government of Sri Lanka happened to take over the sole responsibility for implementing the DDR process have raised serious concerns both at the local and international level. Hence, this article attempts to conduct a detailed inquiry of the DDR process implemented in Sri Lanka after the end of the civil war. This article followed a descriptive method of investigation. The findings of the study show that the DDR process was not fully implemented in a broad manner in the Sri Lankan context, but only served as a continuation of the military victory over the LTTE. In particular, not much attention was paid to disarming and demobilizing the armed groups, and only the so-called DDR process took place without international assistance and supervision.
\end{abstract}

Keywords: disarmament, demobilization, reintegration, peacebuilding, civil war

\section{Introduction}

Peacebuilding is a continuous process that is generally undertaken by the support of the international community, and it is an essential long-term process after the end of a war. Following a protracted civil war, it is crucial to rebuilding the peace and harmony among war-torn communities (Department of Peacekeeping Operations [DPKO], 1999). In Sri Lanka, the war with the Liberation Tigers of Tamil Eelam (LTTE) was brought to an end in May 2009 after defeating it militarily, and there were talks of emphasizing development from then onward. However, the expected growth never took off satisfactorily due to the lack of sustained interest by the successive governments. It had terrible consequences and led to many difficulties that the people had to face.

After the independence of Sri Lanka, ethnic relations among communities were characterized by the ruling Sinhala elites and their political agenda that mainly focused on excluding the Tamil speaking minorities from the mainstream political arena. On many occasions, ethnic minorities were subject to ethnic discrimination and subject to other strictures, which eventually led to the armed conflict. Even when proposals to address the Tamil minorities' grievances were put forward by some Sinhala leaders, they were obstructed by chauvinists among the majority community. Peaceful protests by the Tamils eventually transformed into a violent uprising of Tamil youth, and it took on a new dimension after the July 1983 pogrom against the Tamils, which drew international attention and criticism (Fazil, 2019).

The war between the LTTE and the government raged for nearly three decades. In 2007, the LTTE was defeated in the Eastern province, and subsequently, the government initiated post-war development and peacebuilding activities in the region. In keeping with that, the government commenced disarming, demobilizing and reintegration process as a prelude to establishing peace in the area. When the LTTE were defeated militarily, they were immediately disarmed and demobilized. The government took the measures to rehabilitate and reintegrate them into society, and it was considered an essential step to rebuilding peace in the region. Unfortunately, in 2004, the LTTE's Eastern province commander Karuna's faction did the exact opposite and mobilized itself into an armed group. After the war ended in the East, Karuna's and Pillaiyan's armed groups began operating as 
paramilitary forces that worked with the government forces (International Crisis Group [ICG, 2010]).

As the government forces expected to get their help to defeat the LTTE in the North, they allowed these paramilitary forces to operate somewhat freely, which was entirely against international conventions governing post-conflict situations. Because of that, the DDR process initiated in the Eastern province of Sri Lanka failed to get the necessary assistance and expertise from the international community. As a result, the programmes started to assist the local communities in the Eastern province to return to their earlier pre-conflict life and the scheme to reintegrate the ex-combatants into society, and develop the local economy under the "Eastern Re-awakening" program failed. Ex-combatants of the particular area are continuing to live facing many difficulties and challenges even eleven years after the end of the war.

The DDR process is usually implemented when a country involved in an internal or external war contrives to end that war. The critical point is that this process is generally supposed to include external parties like other governments and international institutions that will provide funding and expertise while also supervising the operations. However, in Sri Lanka, the DDR process was undertaken in its entirety by the government without foreign participation. It caused many problems and posed challenges to those who were supposed to be the beneficiaries of this process. This state of affairs has also created suspicions. The DDR practices followed by the Sri Lankan government have not been in keeping with the prescribed international conventions and guidelines and have deviated markedly from them. When a war is over, the fighters of all militant and paramilitary groups should be disarmed and demobilized to ensure positive peace. Granting amnesty, reintegrating ex-combatants into society and reviving the economy so that their lives can be brought to a healthy state. Against this backdrop, this study attempts to analyze to what extent the international standards and norms in respect of the DDR have been adopted in the war-affected areas of Eastern Sri Lanka.

\section{Research Methodology}

This is a qualitative study based on primary and secondary data. Interviews and limited observations were used to collect primary data while previous studies, research journals, articles, books, newspapers and circulars were used to gather secondary data. The selection of the sample for the interviews was made from a cross-section of society based on who would be the most suitable individuals for this. Interviews were conducted with 30 individuals comprising 21 ex-combatants, 02 ordinary citizens, 03 private-sector employees, 02 government employees, and 02 senior civil servants. The information obtained from the interviews was transcribed, and according to the responses, were matched to the research objectives. They were then subject to analysis. This study was restricted to the Kiran Divisional Secretariat area in Batticaloa district and covered only the adult ex-combatants.

\section{Results and Discussion}

\subsection{Disarming Ex-Combatants}

A primary step that must be taken before any initiative can be taken to build peace at the end of a war is to disarm ex-combatants. Whether a war is brought to an end by means of a peace treaty or through the military defeat of fighters, the first essential step that must be taken is to disarm them if permanent peace is to be built up. In that context, this process must be conducted with the assistance and oversight of international players. In 2007, when the Tigers were militarily defeated in the Eastern province, that should have been immediately followed by disarming the remaining ex-combatants. However, it did not happen appropriately, although some notable disarming operations did occur. On $01^{\text {st }}$ March 2009, Pillaiyan's group formally surrendered its weapons to the army at the Weber Stadium in Batticaloa (ICG, 2010). Further, it is well known that during the end of the war, many fighters had discarded their weapons in wooded areas and on the roads and escaped. According to the above reports, many others who had surrendered to the army had left their guns at a junction in Pulipainthakal.

In this regards, an ex-combatant made the following observation:
"When we were fighting in forests, we broke up into small groups and at one stage were without food and water. We had also lost communication with other groups. Then we thought there was no point in keeping the guns and threw them away. We then left the forest and surrendered to the army, who questioned us about our weapons. When we explained what happened, they accepted what we said and did not question us about the weapons thereafter. Now even we do not know the fate of all those firearms" (Interviewee 2). Another ex-combatant stated, "We heard that some fighters came and dropped their weapons at Pulipainthakal and simply returned home without facing any hindrance. No one knows what happened to all those abandoned weapons" (Interviewee 9).

The foregoing observations constitute the only information that could be accessed by this study regarding the 
disarming process. The disarming should have occurred strictly according to the procedures laid down by the DDR protocol. In particular, the disarming process should have been conducted by the government with the assistance of NGOs (Non-Governmental Organizations), as this procedure involves estimating, collecting, storing, cataloguing and destroying the weapons. However, the Sri Lanka Government did not function in that manner. Further, the disarming of the paramilitary groups was also done by the government in a non-systematic way. The International Crisis Group commented on this in the report of a survey it undertook in 2009. The report states that only some weapons were collected and even after that, it was possible to see armed Tamil Makkal Viduthalai Pulikal (TMVP) cadres moving about freely. In connection with this, the government's position was that the weapons had all been collected and that the TMVP had registered itself as a party and joined the political mainstream.

\title{
A former TMVP member had this to say about it.
}

\begin{abstract}
"As the TMVP is now functioning as a political party, we were instructed not to carry any firearms around. In 2010, they said that anyone who wished to return home could do so. Therefore, before I left for home, I handed over the weapons I had in my possession to a responsible officer who simply took them over without saying anything. After that, I have no idea what happened to those weapons" (Interviewee 12).
\end{abstract}

From the foregoing, it is clear that the disarming was not carried out in a timely and transparent manner. There were also many conflicting reports regarding how the disarming activities were actually carried out. It is apparent though that the government of the time worked with the Karuna and Pillaiyan groups by making them official or unofficial partners of the government and got them to engage in armed activities against the LTTE. When the war ended, this eventually resulted in the 'unemployed' armed groups aiming at civilian targets in the Eastern Province. There was more violence, lack of security, illegal taxation, demands for 'protection' money, murder, robbery and abductions, etc. This study found that no concerted effort seems to have been made by the government to collect the stray weapons held by civilians. Upon inquiring from the security forces about this, the stock reply given was that since this is a matter connected with national security, no disclosures could be made (ICG, 2009).

Therefore, one reason that the disarming was not implemented satisfactorily even though the war ended long ago was that the security forces defeated the LTTE in confrontation (Antonovskaya, 2015). The other reason was that the security forces wished to make use of the smaller armed groups in their fight against the LTTE. It was for these reasons that the international institutions and non-governmental organizations were kept out of the disarming process. Further, the government also wished to continue using these groups in its fight against the tigers and wanted to ensure that there would be no obstacles against this course of action. Therefore, it is clear that is what motivated the Government of Sri Lanka (GoSL) to act on its own in disarming the militant groups in the East. The result was that disabling of the militants was not done the proper way. Of course, this had several adverse consequences in the Eastern Province, such as the inability of the state to maintain law and order, a lack of social and economic development, and insecurity for the people.

\subsection{The Demobilization of Armed Groups}

The purpose of demobilization is to disband the militant and paramilitary groups officially in a systematic and controlled manner. This process is something that ought to be undertaken by international and national NGOs. Mainly, the disbanding and demobilization of militant and paramilitary groups is a process that must be verified by foreign actors. Demobilization is implemented in two phases. During the first phase, the ex-combatants are accommodated in temporary shelters, and during the second phase, additional support is provided. This is known as re-insertion. This help is rendered during the demobilization when individual ex-combatant are put up in temporary shelters, and a special assistance package is granted to them. This is done with funding by international financial institutions, and it is well planned. Funds are also provided to the families of fighters who are affected or injured by the war. Their urgent needs are attended to as prescribed under the DDR principles (UN, 2000).

In the Eastern province, though, the peacebuilding process after the end of the war did not receive the benefit of any international community. In contrast, the armed groups transformed themselves into paramilitary groups that began functioning under the army's guidance, according to the findings of this study. Many LTTE fighters surrendered to the military while some of them went to stay with relatives or friends (Interviewees $12 \& 14$ ). There is still no information about the fate of a large number of cadres who left the LTTE at the end of the war. One thing is clear, and that is the wartime government, instead of demobilizing the armed groups in the Eastern Province, made use of them as a tool to weaken the Tigers by attacking them. Many LTTE cadres were forced to 
join the TMVP. In particular, after the 2004 split in the LTTE, two of its senior members, namely Karuna and Pillaiyan, left the organization and formed their own groups. When these groups spotted any ex-LTTE members, they would employ firm persuasion and compel them to join their groups.

There were instances when those who refused to join were shot and killed at night. To avoid these risks, many of the young men left the area for other places in the country. Some of them obtained employment in Middle-East countries while others went to European countries and claimed political asylum. Several young men who left the country during this period of turmoil returned home later when the war ended, hoping they would be able to live a peaceful life from now on. However, many of them were taken into custody at the airport itself on landing. Those who managed to reach home safely were again forced to join the paramilitary groups, which continued to operate even after the war. Those young men who were better off could avoid forcible recruitment by giving the groups large sums of money. Because of these types of harassment, many of them decided to stay permanently in foreign countries (Interviewee $1 \& 18$ ).

However, not only did the government fail to take any action against these groups, it even allowed them to act in breach of law and order, apparently with its tacit permission. In connection with this, a social worker observed that when complaints were made to the police and the army about various unlawful activities of these groups, these agents of the state omitted to take any action against the culprits. Members of the public commented that the government had nurtured these murderous and destructive groups and had made no move to control their activities (Interviewee 3).

An ex-combatant stated as follows regarding this.

"In 2004, when the Karuna faction split from the LTTE, we were asked to return to our homes. Then I went to Qatar and remained there until 2007. When I returned home that year, the TMVP said that I was a former LTTE fighter and forcibly inducted me into the TMVP. When I refused, they threatened me by saying that if I don't join them, they will not leave my brother alone. As I was concerned about my brother, I agreed to join them. During this period, we worked alongside the army. We simply did what our group leader told us to do. I was in the political section and assigned responsibility for inquiring into complaints made by the public and finding solutions for them. On some occasions, payments were levied in the name of our group leader. Later, when the TMVP became a political party, I left the group and went abroad again" (Interviewee 1).

In keeping with the international guidelines applicable to demobilization, ex-combatants entering civilian life along with their families are entitled to receive necessities such as food, clothing, shelter, medical services, short-term educational services and security. Further, some of the recommendations to be followed during the demobilization process are registering the fighters, recording their brief history, maintaining them temporarily, collecting the necessary information needed to rehabilitate them and laying the groundwork to reintegrate them with society. Additionally, they must be adequately vetted to check for previous criminal activities, and then identification documents must be prepared for them; they must also be provided with food, medicine, shelter, security and emergency aid. However, these are short-term measures that will precede the long-term re-integration process (UN, 2000).

Though these processes were performed sporadically and here and there in the eastern areas after the war, they were not implemented fully with the involvement of any international agencies and no emergency aid was provided either. The re-insertion process for the militants and their families also did not take place. Instead of that, these persons were made to stay in the same transit camps as all the other people who were internally displaced during the final stages of the war. This setup, instead of preparing the ground conditions for re-insertion only served to cause various other problems for the fighters and their families. Militants who escaped the battlefield to save their lives were viewed with fear and revulsion by the civilian society. Further, some militants who could not fulfil their basic needs in the same way as the civilians began to engage in unlawful and antisocial activities. Many militants who found it challenging to make the change back to civilian life returned to join Karuna's and Pillaiyan's groups (The University of York, 2011).

Referring to this matter, an ex-combatant expressed his views.

"I was holding a very responsible position in the LTTE for 08 years. During the final stage of the war, we were isolated in the forest without supplies, and so we surrendered to the army. After a short inquiry, they allowed us to go. Our leader Pillaiyan helped to get us released by speaking to the army officers. As I had spent the past 08 years as a fighter dedicated to our struggle and had lost touch with my family, at the end of the war, I felt alone and abandoned. As I did not know where to go, I followed the crowd and stayed in the Santhiveli transit camp. It struck me that everyone was looking at me rather 
oddly. Some appeared frightened of me. Some looked at me with revulsion. Some others whispered among themselves when they saw me. No one seemed ready to accept me or interact with me. Because of that, I could not speak with anyone. I felt guilty as if I had done something that I should not have done. As I could not move with the people to meet my daily needs, I returned to my former leader Pillaiyan and rejoined his group. Now I am working as a member of his party" (Interviewee 19).

Thus, the DDR process does not appear to have been appropriately planned and with the collaboration of international finance and other agencies. Nevertheless, some local NGOs had participated fully in this work. Further, the government had also obtained assistance from international organizations like USAID (United States Agency for International Development) and UN-HABITAT (United Nations Human Settlements Programme). Anyway, there was only minimal participation by UN-affiliated bodies (UN - United Nations). These organizations are also supposed to have provided assistance through the government. The findings of this research suggest that international financial support was somewhat curtailed and less than what it should have been. The state of affairs that prevailed in Eastern Sri Lanka indicates that the attempts to establish peace and reintegrate the ex-combatants into society were not successful because the Government of Sri Lanka did not follow the DDR guideline. Therefore, the question was posed as to what were the actual results that were obtained from the reintegration process implemented by the government, and so the data pertaining to this was analyzed.

\subsection{Reintegration}

Reintegration is a long-term process that is aimed at connecting the ex-combatants with society and the economy. The objective of this process is to persuade and convince the fighters to adapt to civilian life and to take up some permanent occupation to earn a steady income. Local and international Non-Governmental Organizations undertake this type of procedure. The DDR Guideline enunciates internationally accepted principles for reintegrating militants after the war or end of hostilities. They prescribe a reintegration process aimed at accommodating them into society by rehabilitating them, granting them a pardon or blanket amnesty, resettling them, giving them land, helping them to construct a house, and providing training for some occupation or self-employment project (DPKO,1999; UN, 2014). It is no less essential for them to gain acceptance in society, and to receive psychological support. The guideline also elaborates on how the political rights of the rebels who have come to a settlement must be protected and besides makes many other recommendations on how to treat them (Gleichmann, Odenwald, Steenken, \& Wilkinson, 2004).

The DDR Guideline is comprehensive and deals extensively with the issues relating to the militants and their families. Special attention is focused on their needs, and stress is laid on the importance of the reintegration process. The guideline lists strict rules on how the social and economic status of the ex-combatants must be developed to facilitate their reintegration with society, and how the aid institutions, the national government, the security forces and civil society organizations should make their contributions (UN, 2000).

Unfortunately, the reintegration process followed by the Sri Lanka Government deviated markedly from the procedures outlined in the DDR Guideline. The entire process fell under the purview of the security forces with a few local NGOs to help them out. Thus, the whole process was implemented in accordance with the strategy and procedures formulated by the government, which varied markedly from the internationally accepted DDR Guideline. The arbitrary approach adopted by the government to implement the DDR resulted in adverse consequences that made things worse for the ex-combatants, their families and even the public because the process was implemented without much thought to their real needs. Further, this process did not include all of the affected parties in society. The undue interference and lack of transparency of the security forces could also be clearly discerned. Another issue was that the information and reports issued by them about the reintegration process were incomplete and full of contradictions.

\subsection{Rehabilitation of Ex-Combatants}

Rehabilitation is the initial process of re-educating the ex-militants to abandon their violent approach to solving problems and follow the peaceful and democratic path so that they will be able to integrate themselves into society and participate in the economy as ordinary citizens. This process includes all of the militants within the affected community. According to information released by the government, 11,664 fighters who surrendered at the end of the war were sent to 06 rehabilitation centres to undergo rehabilitation (Thalpawila, 2015). According to Hettiarachchi (2018) indicated that 12,206 beneficiaries were rehabilitated and reintegrated with their host community (p. 278). However, no information is available about the rehabilitation process that was implemented with respect to the fighters who surrendered in the East. It is known that this rehabilitation process included very few LTTE and TMVP members. According to Batticaloa, district government records only 260 former militants 
were taken in for rehabilitation. This included 220 males and 40 females. Of this number, 38 militants were from the Kiran Divisional Secretariat Division where the research was conducted. This number comprises 33 males and 05 females (The data appears in the following table).

Table 1. Summary of rehabilitated persons in Batticaloa District

\begin{tabular}{clccc}
\hline Se.No & DS Division & $\begin{array}{c}\text { No. of } \\
\text { Rehabilitated } \\
\text { Persons }\end{array}$ & Males & Females \\
& & 81 & 62 & 19 \\
\hline $\mathbf{1}$ & Eravur Pattu, Chenkalady & - & - & - \\
$\mathbf{2}$ & Eravur Town, Eravur & - & - & - \\
$\mathbf{3}$ & Kattankudy & 28 & 27 & 1 \\
$\mathbf{4}$ & Koralaipattu, Valaichenai & - & - & - \\
$\mathbf{5}$ & Koralaipattu Central, Valaichenai & 27 & 22 & 5 \\
$\mathbf{6}$ & Koralaipattu North, Vaharai & - & - & - \\
$\mathbf{7}$ & Koralaipattu West, Oddamavadi & 21 & 20 & 1 \\
$\mathbf{8}$ & Manmunai North, Batticaloa & 9 & 7 & 2 \\
$\mathbf{9}$ & Manmunai Pattu, Arayampathy & 9 & 8 & 1 \\
$\mathbf{1 0}$ & Manmunai South \& Eruvil Pattu, Kaluwanchikudy & 14 & 10 & 4 \\
$\mathbf{1 1}$ & Porathivu Pattu, Vellavely & 17 & 16 & 1 \\
$\mathbf{1 2}$ & Manmunai West, Vavunativu & 16 & 15 & 1 \\
$\mathbf{1 3}$ & Manmunai South West, Paddipalai & 38 & 33 & 5 \\
$\mathbf{1 3}$ & Koralaipattu South, Kiran & $\mathbf{2 6 0}$ & $\mathbf{2 2 0}$ & $\mathbf{4 0}$ \\
\hline
\end{tabular}

(Source: District Secretariat, Batticaloa)

Further, all of these ex-militants were from the East, but they had been taken to the Vanni for the purpose of rehabilitation and then brought back. They were forced to surrender or voluntarily surrendered during the final stage of the war that took place in the North in 2009. The study found that many of them had been trained in the East even before the year 2000 and then sent to the North. As for the 6000 fighters who are supposed to have fought in the East (ICG, 2010, p. 3), there is no information in any government documentation regarding any rehabilitation process that was conducted for them. A government official commented about this as follows,

"I am not aware of any persons from this area who were rehabilitated. However, I know that some persons who were rehabilitated in the Vanni have been resettled here. No one from this area likes to identify himself / herself as an ex-combatant. As far as the Kiran area was concerned, there was a militant from nearly every household. Due to fear that they would suffer repercussions, most of them conceal their past. Some people hide because they are worried they would be harassed by the army or the CID" (Interviewee 21).

A National Action Plan (NAP) of the National Framework Proposal for Reintegration of Ex-combatants into civilian life in Sri Lanka has formulated a framework known as "Protective Accommodation and Rehabilitation Centre (PARC)" to reintegrate the ex-combatants. This process involved only the limited participation of international institutions like IOM (International Organization for Migration), ILO (International Labour Organization) and USAID (United States Agency for International Development). Other international institutions, local NGOs and civil society bodies did not participate. At the same time, no information is available about the rehabilitation process that is supposed to have been conducted for the ex-combatants of the Eastern region. Even the district and divisional level government officials do not appear to have any information regarding this matter, and there seem to be no official records or documents pertaining to this matter either (The University of York, 2011).

According to the findings of this study, this process should have been undertaken and conducted by international 
NGOs. Still, the Government of Sri Lanka ignored the DDR Guideline and refused to allow independent international supervision over this process of rehabilitation. Furthermore, because the international aid organizations were forced to work under many restrictions imposed by the government, they were unable to work according to their official mandate. In addition, there is no evidence that the TMVP members or anyone belonging to the Karuna group were ever required to undergo the rehabilitation process. Research suggests this, but there is no government documentation or NGO documentation to confirm this. The answer to the question whether the members of the paramilitary groups that functioned in the East were subjected to a rehabilitation process seems to be a 'no'. In connection with this, a former TMVP member said,

\begin{abstract}
"We did not go through a rehabilitation process. When we surrendered during the final phase of the war, we were worried that we might be forced to go through a rehabilitation process, but our leader Pillaiyan saved us. If you ask me, I would say that we do not need to go through any rehabilitation because we have transformed ourselves into a political party and are now serving the Tamil people. We wish to join the government and work for the benefit of our people. Therefore, there is no need or any point in our going through a rehabilitation process" (Interviewee 19).
\end{abstract}

According to the internationally accepted DDR principles, after undergoing rehabilitation, the ex-combatants must be absolved of all charges brought against them due to the militant roles they played during the insurrection or rebellion. They should be freed of all charges under a general amnesty or granted exemption from prosecution (UN, 2000). Despite that, many ex-combatants were not allowed to go free even after going through rehabilitation. Particularly, the high-level cadres and combatants who played leading roles are still being held in custody as "political prisoners" even after 11 years. Upon scrutinizing the available records of those who were freed, it is apparent that none of them occupied a decision-making role in the LTTE hierarchy and only served as ordinary combatants. In particular, no information at all is available about the LTTE's intelligence operatives and troop leaders. It is well known though that some notable TMVP leaders have been attached to the army's intelligence division. Some of them are working overtly as army intelligence operatives while some others are doing the same work covertly, according to the Interviewee 14.

The rehabilitation process was also not conducted in an independent and responsible manner. Many of the rehabilitated ex-combatants were subjected to surveillance. Several others who had surrendered voluntarily or forced to surrender were sent to the rehabilitation camps only after being kept in custody for several months. The lack of independence, transparency and protection in the reintegration process for combatants is clearly visible. What is more, many complaints were also received about human rights violations against those who were to be rehabilitated. In the report released by the 'Tamils Against Genocide' institution, it was revealed that the highly secure rehabilitation camps were located in places that were difficult to access by family members and the staff of NGOs (Tamils Against Genocide, 2014).

\title{
3.5 Resettlement
}

The ex-combatants and their families that were displaced during the war were to be resettled in their own places. The government must allow this if the people wanted to go back to their earlier locations. In keeping with this idea, the government resettled the rehabilitees and their families back in their former places when the war in the East ended in 2007. There were no longer any people in the transit camps as they were resettled in their own areas. Many of the affected ex-combatants had been given houses through various housing schemes. Those who did not possess any land were given government land. Not everyone was covered though because even now some rehabilitees have not been offered any land or house. It is notable that many army camps have been removed and the properties there have been restored to the former owners.

Once the ex-combatants have been rehabilitated and resettled, the government is expected to provide them with livelihood arrangements. The government must prepare for this even as the rehabilitation process is being carried out. To those engaged directly in the war, that in itself constituted their life. As most of them were lacking in livelihood skills and unable to fulfil their daily needs, the government had to provide them with suitable training to enable them to survive. This involved providing them with job opportunities to match their skills, essential work equipment, as well as business loans required for self-employment projects. Arranging all these was a necessary responsibility of the government. Even though organizations such as IOM, ILO and USAID provided training for LTTE and TMVP members in carpentry, bricklaying and plumbing, etc. during rehabilitation, there continued to be a lack of work for the artisans possessing these skills. Those who were able to find job opportunities in other countries have gone abroad. Some of the former combatants have been absorbed into the government security apparatus. As agriculture is the primary livelihood of people in the Kiran area, the training provided to the ex-combatants has not proved very useful to them. The IOM has given some cattle to a limited 
number of persons (The University of York, 2011).

\subsection{Challenges to Be Faced}

Even though 11 years have passed by since the war ended, there are few discernible signs of any reduction in the challenges facing the rehabilitees. Despite their re-introduction to society, the challenges they are continuing to face are proving to be an obstacle to reintegration. Whereas the physical infrastructure to accommodate them has been developed to some extent, the social, economic, and security-related challenges continue to plague them.

\subsubsection{Social Challenges}

During the reintegration process, the gap between the rehabilitees and society should be reduced in order to build up social harmony. Civil society organizations, private and public associations, heads of religious orders and other influential social groups should be a part of the process aimed at accepting all these people back into their host community without ostracising them. In fact, this type of process never took place in the East. Some ex-combatants were rehabilitated and resettled, but they were not reintegrated into society and never received social acceptance. Because of that, the rehabilitees continue to suffer rejection and have to bear the taunts of ordinary citizens. Even some social service institutions fail to recognize them and assist them. A more distressing occurrence is that many disabled ex-combatants such as amputees or those who suffered other serious injuries are often treated with ridicule. They complain that they are purposely ignored by village-level associations. In particular, they are not allowed to participate in the village development committees, women's development associations, youth clubs and temple administration committees, etc.

In connection with this issue, a former combatant related his experience as follows.

"I lost my right arm during the final battle encounter. Whenever I have a problem with others, they abuse me openly with reference to my disability using words such as cripple, armless person and other derogatory words. They also keep saying that for the way I conducted myself earlier, this is what would eventually happen. More than me, the things they say cause much distress and mental anguish to my wife. Because of that, I feel that even if they don't help me, that is okay, as long as they don't speak ill of me and treat me like this" (Interviewee 5).

Another affected person stated,
"I attended the temple administrative committee meetings several times, and it gradually dawned on me that none of them seemed to desire my presence. They used to mutter amongst themselves as to why I was attending. Because of that, I stopped going to these meetings. But the fact is that most of those in the committee were also ex-combatants. I realized they were behaving this way due to their awareness of my past activities, so I gradually stopped my participation in everything. When I say that I never did anything on my own but only did what I was told to do, they refuse to accept that" (Interviewee 17).

Further, the ex-combatants live in the same house as part of an extended family that includes the father, mother, married sister and her husband and the unmarried sister for example, which can give rise to many social challenges. It often leads to social degradation and family breakups. There have been instances when the unmarried girl in a family becomes pregnant, and the other family members wonder whether it was the father or her brother-in-law who was responsible for her condition. In many families in which the husband had died in the war, his widow becomes the head of the family. Such families face many social challenges. Notably, as the mother has to go out to work for the family's livelihood, the children may not go to school, or sometimes the children too are forced to go and work somewhere. There are frequent incidents of sexual abuse of young girls who are left alone at home. Fearing this possibility, many mothers marry off their daughters at a young age, and this often results in pregnancy while the girls are still in their teens.

\subsubsection{Psychological Challenges}

A part of the reintegration process is to build up the psychological strength of the rehabilitees and build up their confidence. Extra care must be paid regarding their mental health. If they had been subjected to severe stress or mental trauma, they should be provided with psychological support and be given psychotherapy. It is possible to confirm that this procedure has taken place. Even during and after rehabilitation, the ex-combatants have received psychological support. Particularly in the East, following resettlement, they received mental therapy at the Family Rehabilitation Center for a period of six months (Interviewee 11). During these sessions, the affected persons used to be given therapy for 03 hours continuously to build up their mental strength. Despite all that, many of these persons continue to live with psychological disorders that continue to torment them.

These people have become depressed due to the discrimination, ostracism, neglect, ridicule and similar negative 
treatment meted out to them. Many of those who participated in the battles had been traumatized by the sight of their comrades being killed and maimed before their very eyes. Some of the symptoms they used to manifest were the following: disturbing and frightening dreams, insomnia, preference to be alone, irrational and intense fear, being always on edge, rough or violent temperament and action, not concerned about personal safety, crying without any reason, and tendency to scream suddenly. While these are symptoms that cause much concern, many of them are afflicted with more serious psychological problems.

\subsubsection{Economic Challenges}

After reintegration, the ex-combatants should be linked with the economy, as this is essential for their survival. The economic infrastructure that was damaged or destroyed during the war must be re-established. In order to enable people to acquire their daily needs, they must be provided with employment or self-employment avenues. This major restructuring process is best implemented with the assistance of international funding agencies. The DDR Guideline points out that this should become part of the national development program after the end of a war. After the war ended, redevelopment in the East was started under the "Eastern Re-awakening" program. This plan encompassed the development of basic infrastructure and small-scale industries. Under this program, attention was focused on roads, bridges, electricity distribution, harbour development, irrigation tanks and tourism facilities, all of which were developed or rebuilt. Unfortunately, this program did not cover the Kiran area, which lay severely devastated at the end of the war. By some chance, a few tanks and sluices were reconstructed in some places to meet irrigation needs as well as to provide drinking water. However, no major development has been done in Kiran, though there is a great need for it.

Because of this, many people are without a satisfactory means of livelihood. Apart from agriculture, no other avenues for employment have been established there. Though agricultural lands abound, the irrigation facilities do not provide water as and when needed. The lands of chena cultivators often contained Johnny mines and land mines, which posed a danger to the people working there. Farmers complained that on several occasions valuable cattle had stepped on these mines and been maimed or killed. Another frequent complaint received was that the military was also engaged in livelihood activities, in direct competition with the people of the area, thereby depriving them of an income. They further complained that the army had established camps on their lands and was engaging in chena cultivation. The army was involved in commercial activities that ranged all the way from running small shops to operating big hotels. As the people, both rehabilitees and ordinary civilians found it difficult to compete with the army and its resources. They often found themselves stuck at home with no prospects of earning a livelihood. Whenever they got the chance, they engaged in small-scale agriculture, and during the harvesting season, they would go and work in other people's fields.

The government has failed to launch a people-centred economic development plan. Though self-employment loans are available, there is a stipulation it must be conducted in partnership with others, but the loan amount is too small to start a partnership business they say. Further, the disabled are paid only Rs.3,000/- a month in the case of a three-member family, but this amount is insufficient to meet the expenses of even one person. Therefore, they are reduced to penury they say and find it challenging to meet even their basic needs. They complain they are undergoing great hardship (Interviewee 2). The IOM had donated some cattle to a limited number of ex-combatants, but the beneficiaries say that even then they face considerable challenges in maintaining the herd. Notably, there is only limited pastureland available for grazing, and during the rainy season, the cattle have to be taken to the forest due to flooding. When there is drought, the cattle have to be kept all the time close to ponds or lakes, and this was also proving to be a big challenge to them.

\subsubsection{Security-related Challenges}

According to the DDR process, after the war, the government should ensure reliable social security as a prerequisite for establishing permanent peace. Further, an environment must be created in which ex-combatants, civilians, governmental and non-governmental institutions, and civic organizations can function freely and independently. Further, restrictive security measures, unnecessary checkpoints, guard posts and military camps should be removed. The roads must be opened for the people and traffic to move freely (UN, 2000). Some of these provisions were indeed put into effect in the East, but the authorities could not ensure social security. Because of the intrusions of the security forces and the illegal activities of the Karuna and Pillaiyan groups, several injustices were perpetrated on the people. Until the TMVP and the associated factions transformed themselves into political parties, there was no guarantee for the life of the people in the East. That was a critical period when killings, abductions and disappearances used to take place routinely (ICG, 2010). Eventually, these illegal activities by the paramilitary groups ceased to occur.

However, the intrusive activities of the army continued as usual. Especially, even 08 years after the end of the 
war, the army intelligence division's harassments are being experienced by the people without end. In these areas, the CID (Criminal Investigation Division), TID (Terrorist Investigation Division) and army intelligence units continue to maintain constant surveillance on the ex-combatants and even the ordinary citizens (Interviewee 05). In this area, everyone including the staff of NGOs, INGOs (International Nono-governmental Organizations), school teachers, government servants, and even people from outside the area are constantly troubled by the intelligence division and prevented from going about their work independently (Interviewee 29). In the case of employees who are to be appointed newly, they are allowed to work only after going through an intelligence screening. Especially, those who work for NGOs, and those who will be working with ex-combatants are not only warned very strongly; all information and documents about them are collected (Interviewee 22 \& Interviewee 24). Under these circumstances, the situation for the ex-combatants was still tight. Unknown visitors could not come to their house. If they wish to travel to other places, they had to give prior notice. They could not work with civic organizations or NGOs. If anything of the foregoing nature happened, they must have immediately informed the intelligence officers. If they failed to comply with these instructions, they were liable to face harassment.

Many former TMVP members were living among the people in the villages, spying on them. They were the ones occupying important positions in the village level institutions and were responsible for handling affairs connected with village development, agreements and transactions. As the army's lackeys, they were the ones who rob partly or wholly the government assistance and donations intended for the benefit of the combatants and the public (Interviewee 30). They were the people who give the information to the intelligence units of the army about new people who entered the area and about any unusual movement or action by the ex-combatants. It was very shameful that for engaging in this deplorable activity, they were paid a monthly stipend by the Government of Sri Lanka that professed to follow democratic ideals and foster freedom.

In connection with this, a woman combatant who fought in the war boldly stated,

"I surrendered to the army on 2009.05.05. After 11 months of rehabilitation, I was released on 2010.04.05 and came here. A few days after I settled here, an attempt was made to abduct me. Some unknown persons who came in a van mentioned my name, wanted to know where I had come from and wished to see me, but I hid myself. Up to now, we do not know who they are. Therefore, on 2010.05.15 I lodged a complaint at Eravur Police Station. Then they wanted me to come for an inquiry. After that, they used to come often and under the pretext of inquiry trouble me. On 2015.03.05, I was again called for an inquiry. I could not go anywhere. They would call me often and want to know where I was and what I was doing. If any distant relatives or someone new came home, they would come to the house and inquire. They kept on troubling me continuously, but I was not scared. I was ready for anything, and so would scold and chase them away" (Interviewee 11).

\subsubsection{Education, Transport and Health-Related Challenges}

The Kiran area that was the main command centre of the Liberation Tigers near the end of the war was severely devastated. Despite that, only minimal reconstruction work was carried out here. The government's main development objectives when rebuilding after the war appear to be small industries and tourism. Because of that, the emphasis was on the construction of highways, superhighways, long bridges, harbours, airports and luxury hotels, all of which were done very quickly. Redevelopment of the infrastructure of war-affected areas was given rather low priority. Where Kiran is concerned, education, transport and health infrastructure are still in a deplorable state. In particular, it is regarded as lagging behind badly in education compared to other areas. Further, in the Kalkudah education zone, it is rated as the most difficult area for teachers. Kiran has the least number of schools and the fewest number of students out of all the areas in the Kalkudah education zone. The pass rate in public examinations is also very low. Shortage of principals and teachers is a serious problem here. Most of the schools have classes only up to Grade 09 or secondary level. A high rate of school dropouts, poor attendance, and only staying away from school are proving to be big problems. While there has been some improvement in education after the war, it is still lagging far behind the other areas.

Healthwise too, the people are facing multiple challenges. Particularly, teenage pregnancy, low birth weight infants, malnutrition among children, high rate of birth abnormalities and poor maternal and neonatal care. There are hardly any hospitals here. In case of a medical emergency, the patient will have to be taken to the Base Hospital Valaichenai or the Batticaloa Teaching Hospital. The roads, transport facilities, potable water supply and other infrastructure, are all in a horrible state. Seventy percent of the roads are unpaved and with gravel or bare earth surfaces. There are a few concreted roads while the others have damaged asphalt surface. Therefore, the public transport service is sparse. Except for certain places, there is no private bus service to other areas. 
After the war, the Sri Lanka Government's post-war development plan appears to have overlooked Kiran. Only the inhabitants of the Kiran area that was severely devastated by the war know about the true nature of the "Eastern Re-awakening” program.

\section{Conclusion}

As far as Sri Lanka's DDR process is concerned, it can be said that it was not implemented in accordance with international DDR protocol the way it is usually done in other countries; it did not involve any collaboration with the UN or any other equivalent global agency. Instead, the process was implemented by the security forces with the assistance of a few local and international NGOs under the direction of the government. Their objective was to bring about reintegration by following the DDR process according to their own methods and expecting an outcome that would be in keeping with the UN Guideline (2000).

This process was hastily followed as a natural consequence of the military defeat of the LTTE. Those who implemented it failed to pay sufficient attention to the preliminary steps of disarming and demobilization before attempting reintegration. According to the findings of this study, at the end of this process was the achievement of a result that could be called reintegration only in name. Further, even though more than 11 years have elapsed since the armed conflict in the East was brought to an end, the ex-combatants have still not been reintegrated into the society and the economy successfully. This study reveals that they are continuing to face social, economic, psychological and security related challenges even now.

\section{References}

Antonovskaya, V. (2015). Disarmament, demobilization and reintegration (DDR) in the context of a total victory: Elimination or evolution of the concept - The case of Sri Lanka. (Unpublished Master's thesis). Norway: Centre for Peace Studies, Faculty of Humanities, Social Sciences and Education, the arctic university of Norway. Retrieved from https://munin.uit.no/bitstream/handle/10037/9242/thesis.pdf?sequence=4

Department of Peacekeeping Operations [DPKO]. (1999). Disarmament, demobilization, and reintegration of ex-combatants in a peacekeeping environment: principles and guidelines (United Nation Guideline on $D D R$ ). Retrieved from https://www.somali-jna.org/downloads/DD\&R\%20UNPKO.pdf

District Secretariat. (2018). The number of rehabilitated persons in Batticaloa District. Batticaloa: District Secretariat.

Fazil, M. M. (2019). State-minority contestations in post-colonial Sri Lanka. Journal of Educational and Social Research, 9(4), 157-165. https://doi.org/10.2478/jesr-2019-0065

Gleichmann, C., Odenwald, M., Steenken, K., \& Wilkinson, A. (2004). Disarmament, demobilization and reintegration a practical field and classroom guide. German Technical Co-operation, The Norwegian Defence International Centre, Pearson Peacekeeping Centre, \& Swedish National Defence Colleg. Retrieved from https://www.cimic-coe.org/resources/handbooks/ddr-handbook-eng.pdf

Hettiarachchi, M. (2018). Rehabilitation to deradicalize detainees and inmates: A counter-terrorism strategy, Journal of Policing, Intelligence and Counter Terrorism, 13(2), 267-283. https://doi.org/10.1080/18335330.2018.1476774

International Crisis Group [ICG]. (2009). Development assistance and conflict in Sri Lanka: Lessons from the Eastern Province. Asia Report N 165. Retrieved from http//www.crisisgroup.org

International Crisis Group [ICG]. (2010). War crimes in Sri Lanka. Asia Report $N^{\circ} 191$. Retrieved from $\mathrm{http} / / \mathrm{www} . c r i s i s g r o u p . o r g$

Tamils Against Genocide. (2014). Sri Lanka's Rehabilitation of the Liberation Tigers of Tamil Eelam a Programme of Physical and Mental Pacification. UK: Tamils Against Genocide.

Thalpawila, N. (2015). Rehabilitation and reintegration as a key activity of post- war peacebuilding in Sri Lanka. International Journal of Scientific Research and Innovative Technology, 2(12). Retrieved from http://www.ijsrit.com/uploaded_all_files/1898033422_m2.pdf

The University of York. (2011). An evaluation of post war recovery in Eastern Sri Lanka Batticaloa District. (Unpublished Master's Thesis Field Report) UK: University of York, Heslington. Retrieved from $\mathrm{http} / / \mathrm{www} . y o r k . a c . u k$

United Nations [UN]. (2000). Disarmament, demobilization and reintegration of ex-combatants in a peacekeeping environment, principles and guidelines. UNDPKO: New York. 
United Nations [UN]. (2014). Operational guide to the integrated disarmament, demobilization and reintegration standards. Retrieved from http://www.iddrtg.org/wp-content/uploads/2013/05/ OG-2014.pdf

\section{Copyrights}

Copyright for this article is retained by the author(s), with first publication rights granted to the journal.

This is an open-access article distributed under the terms and conditions of the Creative Commons Attribution license (http://creativecommons.org/licenses/by/4.0/). 